\title{
READINGARENDTSONREVOLUTION AFTERTHEFAШOFTHEWAШ
}

Dick Howard*

\begin{abstract}
RESUMO - O artigo revisita a obra de Hannah Arendt On Revolution e os eventos históricos da revolução americana, de forma a reformular os chamados "problemas da época". Embora todo ator político reivindique que as suas políticas sejam a encarnação da vontade unida da nação em uma democracia, abre-se a porta da antipolítica na medida em que a natureza simbólica - e portanto contestada - do povo soberano é reduzida à sua realidade temporária. Tal é a lição crucial a ser extraída ainda hoje da obra The Origins of Totalitarianism, que pode ser lida como uma tentativa de pensar a expressão mais extrema da antipolítica.

PALAVRAS-CHAVE - Antipolítica. Arendt. Democracia. Revolução.
\end{abstract}

\begin{abstract}
The article revisits Hannah Arendt's On Revolution and the historical events of the American revolution so as to recast what Arendt called "the age's problems". Although every political actor claims that its policies are the incarnation of the united will of the nation in a democracy, the door to antipolitics is opened if the symbolic - and therefore contested - nature of the sovereign people is reduced to its temporary reality. That is the crucial lesson to be drawn still today from The Origins of Totalitarianism, which can be read as an attempt to think the most extreme expression of antipolitics.
\end{abstract}

KEY WORDS - Antipolitics. Arendt. Democracy. Revolution.

\section{Introduction: From where do you speak, comrade?}

Two decades after the fall of the Wall seemed to announce - by default, as an unexpected gift - the triumph of democracy, optimism appears at best naïve, at worst an ideological manipulation of the most cynical type. The hope was that the twin forms of modern antipolitics - the imaginary planned society and the equally imaginary invisible hand of the market place - would be replaced by the rule of the demos; citizens together would determine the values of the commonwealth. The reality was at first the "New World Order" of George H.W. Bush; then the indecisive interregnum of the Clinton years; and now the crass take over of democratic rhetoric by the neoconservatives of George W. Bush. "Man is born free, yet everywhere he is in chains", wrote Rousseau at the outset of The Social Contract; how this came about was less important, he continued, than what made it legitimate: that was what needed explanation. So it is today; what is it about democracy that makes it the greatest threat to its own existence?

* Distinguished Professor, State University of New York, Stony Brook, USA.

n. 1

março 2008 
In this context, it is well to reread Hannah Arendt's On Revolution. On returning recently to my old (1965) paperback edition, I was struck by the spare red and black design of the cover, which was not (as I thought for a moment) a subtle allusion to the conflict of communism and anarchism for the realization of 'true' democracy, but simply the backdrop against which the editor stressed these sentences: "With nuclear power at a stalemate, revolutions have become the principal political factor of our time. To understand them may mean to understand the future". Although "nuclear power' clearly referred to the stalemate of the Cold War, it seemed clear that that the 'revolutions' were anticapitalist. Yet, as I began to read that old copy, I was ashamed by both the naiveté and the arrogance - attitudes that often, and not coincidentally, go together - of my marginal comments. Soon enough, alone with myself at my desk, the embarrassment become too great; I decided to order a new copy (2006). When it arrived, I was again struck by its cover, which featured joyfully intertwined clinched fists reproduced from a poster produced during the May '68 Paris "uprising". Having been there, I felt more comfortable for a moment. But then I remembered an oft-repeated question from those times: "From where do you speak, comrade?" The challenge assumed that social class was more important than political action. But the very action of 1968 challenged that gospel ${ }^{1}$. Arendt was not surprised. In "Thoughts on Politics and Revolution", (1970) she recalled the argument of On Revolution, asserting that "[t]his generation discovered what the eighteenth century had called 'public happiness'". Yet, as she weighed its chances of success, her bittersweet and very Arendtian opinion was: "[v]ery slight, if at all. And yet perhaps, after all - in the wake of the next revolution" ${ }^{2}$.

From where, then, do I speak? An American from the Civil Rights generation who went to study in Paris, home of the revolution, but found that the graft didn't take. A 1967 visit to the student militants who would be central to the Prague Spring made me sensitive to the rhetoric of totalitarianism ${ }^{3}$. The first meetings of the 1968 May movement were a revelation: as if those masters of Marxist nuance - eager to distinguish support for the 'workers and peasants' from the broader 'anticolonial' or 'popular struggles of the oppressed' - had suddenly learned pragmatic English! But antitotalitarianism was then the monopoly of the right (which explains some of my marginalia: Arendt never identified herself with such partisan political geography). It would take time for me to understand that the need to think politically was not identical to political positioning. That discovery was facilitated by the discovery of Gordon Wood's The Creation of the American Republic. For an American whose dreams had flown to revolutionary Paris, and whose imagination sought an unspoiled Marxism, the American revolution seemed only a merely political first step toward the social and socialist triumph. That assumption explains others of my misguided

1 The Maoists, who if nothing else held faithfully to their theory by deserting the 'bourgeois' students to "serve the people" of the proletarian districts, succeeded only in making themselves irrelevant quickly.

2 References are to "Thoughts on Politics and Revolution", in Crises of the Republic (New York: Harcourt, Brace Jovanovich, 1972), pp. 203, 231, 233.

3 I met Michael Denneny, who was then Arendt's assistant, that same summer. 
marginalia. Together with the critique of totalitarianism, the so-called republican interpretation of America's self-creation - of which Arendt was not aware when writing her book - suggests the framework for my re-reading of On Revolution ${ }^{4}$.

The present exercise in interpretation is guided by the need to understand the political problems of our times. To see how Arendt helps us to think, I begin (1) by looking at "Her Problems and Ours". What led her to write On Revolution? But also, what questions make us, today, four decades later, receptive to her thought? ${ }^{5}$ Does she recognize that beyond the critique of totalitarianism lies the dawning of a new kind of political life, as Jonathan Schell has recently argued? (2) But the Wall didn't fall from its own inertia. How can one explain the power achieved by the dissidents who transformed the defense of human rights into a new politics? Arendt's essay on Civil Disobedience was written in a specifically American context; but its lessons point further. It appears that that what seem to be today's problems may be the result of judgements that are short-sighted because too directly pragmatic; today's problems may be only a variation on what she calls the "problems of our age". To clarify the broader picture, it is necessary also to look at the relation of "Our Problems and Hers". The actuality of Arendt's judgements turns out to depend on her ability to reactivate philosophical categories that cover over deeper political insight. The very title of The Human Condition indicates that this most systematic of her writings - her answer, many have observed, to Martin Heidegger's Being and Time - indicates that it is not a traditional philosophical investigation of "human nature". (3) But Arendt is not a philosopher; she wants to understand at once how to think and to think events. The two moments are essential, and they are essentially connected. With regard to the American founding, On Revolution goes far toward realizing the first part of this project - to think; but it falls short of the second goal - to articulate the event in its uniqueness. Returning to the actual American history whose significance Arendt intuited but did not fully articulate will permit a better understanding of the dynamics of democratic politics, then as now ${ }^{6}$. In a democracy, politics and antipolitics compete constantly, the excess of the one calling forth the return of the other in a movement whose instability is the paradoxical root of its own strength.

4 I have written about this interpretation frequently. Most recently, in Aux origines de la pensée politique américaine (Paris: Buchet-Chastel, 2004) and, in English, The Specter of Democracy (New York: Columbia University Press, 2002).

5 Need I add that it makes no sense to pretend (as do the neoconservatives) that Islamism - so-called Islamic Fascism - is structurally identically to the old totalitarianisms. To mention but one crucial difference: there are no fellow travelers claiming that the new faith is in fact the "realization" of the principles of the old order.

6 While recent years have brought an end to the decades during which the non-proliferation regime had at least kept the nuclear genie in its bottle, it would be too great a stretch to try to integrate this development into the framework that animated Arendt's original reflections in On Revolution. Arendt's biographer, Elizabeth Young-Bruehl has suggested that a new, non-passive pacifism could be the adequate political response, generating a new kind of popular power capable of facing up to the dead-weight statist Realpolitik. 


\section{Her Problems and Ours}

The 1962 Introduction to On Revolution calls attention to the unique relation of war and revolution in the years after World War II. Because war has become impossible in the nuclear age, "those who still put their faith in power politics in the traditional sense... and, therefore, in war" will have mastered an "obsolete trade." The only remaining justification for war, she continues, is a revolution that claims to defend "the cause of freedom". But like war, such a revolution would make use of violence, which is the "antipolitical" province of technicians, such that its use puts into question the fate of the freedom it professes. This dilemma had been seen already in the $17^{\text {th }}$ century - which, as Arendt notes, had seen its share of violence. It invented the fiction of a pre-political state of nature in order to show that the political realm which is the locus of freedom - does not emerge simply from the fact of people living together. The political is created; it has a beginning that separates it from pre-political life just as the modern notion of revolution claims to inaugurate a rupture with what preceded it. But this act involves a paradox. The need to break with the past in order to found the new means that the new has no proper legitimacy; its only foundation is the "crime" that destroyed the old order. This was the rock on which the French revolution would come to ruin. In Robespierre's version, there could be no virtue without terror, but also no terror without virtue - a dilemma that could not be overcome by the rhetorical institution of the Fête de l'Être suprême.

At first glance, our contemporary situation could not be more different; the Wall just collapsed, its authority broken, its power shriveled. But there was no revolutionary act, the past faded into nothingness almost before anyone was aware that it had gone ${ }^{7}$. But the new order of politics that should have appeared is nowhere to be seen. A revolution without revolutionaries has left a political space without participants. This might have been expected by a philosopher who frequently cited Montesquieu. She liked to recall his account of despotism, whose principle of action is fear - a generalized fear: fear of the state, of one's fellow citizens, even of one's self. Such conditions could never create the solidarity needed to found a political society. But despotism will not fall at the slightest breeze; philosophy, even political philosophy, is no substitute for politics. That is why Arendt insisted on the importance of the event, and the need to think it in a way that makes evident its particularity at the same time that she recognized that theory could not predict what that constituent event would be. (Does this par work? Almost - I made a little change.)

How, then, can it be claimed that democracy "won" the Cold War? Jonathan Schell's Introduction to the re-edition of On Revolution makes a provocative proposal. He recalls the "epilogue" to the 1958 re-edition of Arendt's book The Origins of Totalitarianism in which she reflects on the implications of the 1956 revolution in

7 This is of course not literally true, as we were reminded again in December 2006 when the newly named Primate of the Polish Catholic church had to resign his post before assuming it due to revelations about his collaboration with the secret police of the old regime. This was only the most recent demonstration that the past cannot be simply forgotten or willed away. 
Hungary. He suggests that she never republished this essay because it marked the transition from the bleak pessimism of her account of the totalitarian experience toward the optimism articulated in On Revolution. Schell sees her intuition confirmed by "the wave of democratic revolutions" that he dates from the action and echoes of 1956, rather than the more legalistic Greek, Portuguese and Spanish transitions of the 1970s. In this way, the Hungarian experience represents first expression of a subterranean wave that began to surface with Polish Solidarnosc, passing to the overthrow of military dictatorship in Argentina and Brazil and then on to the Philippines and South Korea, before returning to the former Soviet Union and South Africa to culminate (provisionally) with the fall of Milosevic, the Georgian Rose Revolution and the Ukrainian Orange Revolution. Schell insists on the fact that "most" of these cases looked to the American revolution rather than to the French model; and that they "aimed at establishing conditions of freedom rather than solving social questions". Further, "[a]ll were largely nonviolent...and most interesting and important, they repeatedly vindicated Arendt's new conception of power and its relationship to violence" 8 . Schell grants the importance of a "new conception of the social", in the form of civil society (a category that ill-fits Arendt's theoretical framework $^{9}$ ) as well as a concern with electoral results. Yet, he insists, the similarity of "opposition to regimes as disparate as the military rule of southern Europe, the right-wing dictatorships of South America, and the apartheid regimes of South Africa... make one believe that Arendt was right..." to claim that the "signatories of the Mayflower Compact" had discovered the true grammar and syntax "of any action whatsoever" ${ }^{10}$.

However questionable sweeping generalization that sometimes takes its wishes for reality may be for the historian, its theoretical premise suggests why Arendt's problems help illuminate our own. As she puts it in lapidary form, one cannot say simply that totalitarianism is the problem, the Hungarian workers' councils are the solution. Rather, she insists, both are a response to "the age's problems" ${ }^{11}$. And Jonathan Schell rightly insists that these are still with us in what he calls the "debate" over whether "the wave of Arendtian democratization [has] run its course" 12 . What worries him is the current American policy of "democratizing other countries by armed force" ${ }^{13}$. This was not what Arendt had in mind when, for example in The Origins of Totalitarianism she stressed that imperialism is one of the problems to which totalitarianism is a "fantastical attempted solution". That was surely one reason for her opposition to the American war in Vietnam. Following the same logic,

8 Cf. Jonathan Schell, Introduction to Hannah Arendt, On Revolution (New York: Penguin Classics, 2006), p. xxii.

9 Cf. Jean L. Cohen and Andrew Arato, Civil Society and Political Theory (Cambridge: MIT Press, 1992), Chapter 4, "The Normative Critique: Hannah Arendt", pp. 177-200.

10 Ibid., p. xxvi.

11 Ibid., p. xviii.

12 Ibid., p. xxvi.

13 Ibid., p. xxvii. 
Jonathan Schell hopes that the inversion of the relation between power and violence manifested in the "wave of democratic revolutions" foreshadows a more general reversal of relations between small and great powers ${ }^{14}$. But this hope seems to return to the simple opposition, which Arendt rejected in her first reflection on 1956, where a bad condition that is said to be overthrown by a good alternative. It forgets what Arendt called "the age's problems", which are not philosophical or moral but political. It is not enough to say that "the United States, in pursuit of its war on terror, is losing track of its founding ideals" ${ }^{15}$. To understand America's "ideals", to which Schell like Arendt appeals, we need to look at its politics.

\section{Our Problems and Hers}

Jonathan Schell's "wave of democratic revolutions" has been paralleled by what some have called a "revolution of human rights". The actions of a few dissidents within the former Soviet bloc acquired a political framework when the so-called "Third Basket" of the Helsinki Accords of 1975 (which the Soviets ${ }^{16}$ thought of as a victory for their Realpolitik as it had been exercised in crushing the Prague Spring, affirming the so-called "Brezhnev Doctrine") made audible and public demands for the protection of human rights. While Hannah Arendt was no longer alive, the arguments she had proposed in her essay on "Civil Disobedience", written at the height of the protests against the American war in Vietnam, help to explain how and why the assertion of individual rights came to acquire political significance ${ }^{17}$. She first clears away the usual misinterpretation according to which the civil disobedient is not a criminal because he acts in the light of day and because he accepts the consequences of his act, as in the cases of Thoreau or Gandhi. Rather, acting publicly, she points out, means appealing to others, even if the motive for the act may be hidden deep in the privacy of individual conscience. And action that speaks to others presupposes the existence of a basis for mutual understanding that, when awakened, results in collective action. While this could explain the "wave of democratic revolutions", their success depended also on the fact that the weakened authority of the rulers made them incapable of crushing violently the new politics

14 Ibid., p. xxviii (for these last citations).

15 Ibid., p. xxvii.

16 In the 1976 elections, both Ronald Reagan (in republican primaries) and Jimmy Carter (the democratic candidate) criticized Gerald Ford for signing the treaty. The New York Times' obituary for President Ford (December 28, 2006) quotes historian John Gaddis's 2006 The Cold War: A New History as arguing that it in fact became 'the basis for legitimizing opposition to Soviet rule'. Christopher Hitchens (in Slate, December 29, 2006), points out that Ford's refusal to receive Aleksander Solzenitsyn was a serious blow to Soviet dissidents, while Timothy Noah (in Slate, December 27, 2006) recalls his infamous claim (in a 1976 presidential debate with Jimmy Carter) that Eastern Europe was not under Soviet domination, calling it 'the single dumbest thing ever said by a sitting president in my lifetime'.

17 Cf. in this regard, the seminal essay by Claude Lefort, 'Droits de l'homme et politique,' in L'invention démocratique (Paris: Fayard, 1981); English translation in The Political Forms of Modern Society (Cambridge: MIT Press, 1986). C.f., also Lefort's essays on Arendt in order to appreciate the coincidence (and difference) of their independently developed arguments. I have discussed these issues raised by Lefort in The Specter of Democracy. 
before it spread (as did the Polish coup d'état of December 1981). This is simply another formulation of the interplay of thought and event, authority and action form an indissoluble pair.

More concretely, what seems to have happened is that the civil disobedience that Arendt sought to understand as the renewal of the particular "spirit of American law"18, acquired a power that transcended national boundaries as "human rights" could be appealed to as recognized by international law. The action of the dissidents became unavoidably political at the same time that the Soviet bloc - and what remained of its ideology - lost its legitimacy. But - again! - the simple opposition of black-and-white dissolves the problems that would emerge. After the Fall of the Wall, when neither geo-politics nor leftist hopes for a Third Way could even vaguely justify the denial of rights, the question that worried Jonathan Schell emerged: can rights be imposed at the point of a bayonet? As we saw, Arendt had been aware of the problem already in the Introduction to On Revolution, denouncing it as antipolitical. Although human rights dissidents challenged the residual ("Westphalian") notion of national sovereignty on which the old power politics depended, no new analysis emerged to replace it. Intervention in the Balkans could be justified because it was a "European" concern; but Rwanda was left to its sad fate. This absence of political reflection was at least in part the result of a typical misunderstanding that Arendt criticized in "Civil Disobedience": i.e., a liberal individualism whose appeal to rights ignores their political foundation.

The still-present consequences of this liberal thoughtlessness were suggested recently by Orlando Patterson ${ }^{19}$. Under the title God's Gift? Patterson points out that Americans generally, and the ideologues of the current neoconservative regime in particular, assume that everyone longs for a freedom whose realization demands only that oppression be lifted. 'Once President Bush was beguiled by this argument he began to sound like a late-blooming schoolboy who had just discovered John Locke, the $17^{\text {th }}$ century founder of liberalism. In his second inaugural speech, Mr. Bush declared "complete confidence in the eventual triumph of freedom... because freedom is the permanent hope of mankind, the hunger in dark places, the longing of the soul". Thus, the President told an Arab-American audience, "No matter what your faith, freedom is God's gift to every person in every nation". He drew the implications in another speech that laid out the neoconservative agenda: "We believe that freedom can advance and change lives in the greater Middle East". It would

18 'Civil Disobedience', in Hannah Arendt, Crises of the Republic (New York, Harcourt Brace Jovanovich, 1972), p. 85.

19 Harvard sociologist Patterson, the author of Freedom in the Making of Western Culture published this article as a guest op-ed in the New York Times, December 19, 2006. It is ironic that the first wave of neoconservatives (those of the 1980s) denounced the same naiveté, as Peter Beinart noted in The New Republic (January 1-15, 2007). Beinart quotes Jeane Kirkpatrick's famous 1979 essay, Dictatorships and Double Standards: 'No idea holds greater sway in the mind of educated Americans than the belief that it is possible to democratize governments, anytime, anywhere, under any circumstances. This notion is belied by an enormous body of evidence'. Beinart's point is that the critics of the Bush adventurism are returning to the older 'reality-based' position. 
not be unfaithful to Arendt to suggest that this thoughtlessness - this inability to understand that politics is based on plurality and that it is the result of action by the participants - that is "the age's problem". The problem is not the goals of the neoconservatives; the problem is their political naiveté which forgets the interconnectedness of thought and event, authority and action, politics and possibility. Neoconservatism is an antipolitical politics that dares not admit lives in an eternal present - which is one reason that the Americans were so unprepared once their victorious arms fell silent.

But the thoughtless liberal - or his neoconservative first-cousin - has, however a sort of co-conspirator: the "liberal hawk" who thinks too much ${ }^{20}$. Formerly on the left side of the spectrum, this antipolitical species - for whom Marxism was emphatically not a "humanism" - came to realize finally that the nightmare of totalitarianism is not just a bump in the progress of History toward smiling tomorrows and, enthusiastic as always, jumped on the bandwagon of the campaign human rights ${ }^{21}$. Having defied both the orthodox left and the pragmatic Realpolitiker, these moralists were not deceived by the bromides of soft-hearted American liberalism; they were certain that they could maintain their independence (and thus their influence) while supporting critically the unilateral war of the neoconservatives ${ }^{22}$. It now is (or should be) clear that they were wrong - although some still hold to their certitudes, blaming Bush, or Rumsfeld, or simply faulty execution, for the mess in Iraq in the same way that fellow-traveling leftists blamed the "cult of personality" or "the bureaucracy." However, it would be wrong to throw out the human rights baby with the liberal bath water. Many non-hawk war critics expected the recent report of the independent Baker-Hamilton commission to open a multilateral path for the administration to rectify its voluntarism in Iraq. But even if the report were accepted by the president - which has not been the case - one must still ask: is the return to a "realism" proposed by the Wise Men a desirable politics ${ }^{23}$. After all, it

20 I have in mind here Arendt's friend Harold Rosenberg's description of the Marxist militant as 'an intellectual who doesn't think' because he knows already the necessary course of history and has only to fit the particular events into that pattern. There are former leftist 'liberal hawks' such as the Frenchmen André Glucksmann or Bernard Kouchner, or the Anglo-American Christopher Hitchens; and there are liberal 'liberal hawks,' such as Peter Beinart and his colleagues at The New Republic. For a discussion of some of the issues, c.f., my review-essay on Paul Berman's recent book, of which a French version appeared in La république des idées, a German in Kommune, and an English version will appear in Constellations, Vol. 14, Nr. 3, September 2007.

21 This is more true for the French than the American variant of the species. While the French won rhetorical victories, the Americans made legislative gains. Their denunciation of human rights in the Soviet Union acquired an emotional valorization from association with the Holocaust (which had been absent in the earlier trial of Sinyavsky-Daniel), producing the 'Jackson-Vanik amendment' that pressured the Soviet Union to grant Jews the right to immigrate. Although many later neoconservatives had worked with Jackson, he himself was a staunch, pro-labor Democrat.

22 Did they still remember Lenin's dictum: critical support is that offered by the rope to the hanged man? Will their support have had a similar effect on their neoconservative allies?

23 Even more ironic is the way in which opponents of the Iraq imbroglio appeal to the judgement of the generals who have, from the beginning, opposed the policies of Donald Rumsfeld as well as those of Bush-Cheney. That a critical left should base its arguments on the judgement of the military is, to say the least, surprising. 
was that realism (and those Wise Men) that had led the West to ignore political dissidents, to sacrifice human rights, while practicing the "technique" that Arendt denounced as "antipolitical" because it is based on violence rather than persuasion ${ }^{24}$. The "liberal hawks" do not have the answer to "the age's challenges", but they do at least pose the question; for they too - are seeking to renew the ideals that found democracy, despite their mistaken choice of allies.

\section{On Civil Disobedience}

In this context, Arendt's essay Civil Disobedience has a political significance that cannot be reduced to the similarities of the American war in Vietnam (which was her referent) and the Iraq dilemma. Her essay calls to mind Benjamin Franklin's reply to a bystander as he left the Philadelphia Convention: What have you made, she asked? "A republic, if you can keep it" was the lapidary reply that anticipated a major theme of American history. Civil disobedience, insists Arendt, becomes necessary only when the challenge to the authority of government results in "a constitutional crisis of the first order" ${ }^{25}$. What constitutes a crisis of authority is both the government's overreaching of its constitutional powers and a popular refusal "to recognize the consensus universalis" which founds the tacit agreement holding together the plural threads of the republic. Arendt had denounced the excess of government elsewhere ${ }^{26}$; here she stresses the weakening of those voluntary associations whose foundational role in a democracy Tocqueville had underlined. Civil disobedience is "the latest form of voluntary association;" it is a mode of action "in tune with the oldest traditions of the country ${ }^{27 " . ~ T h o s e ~ t r a d i t i o n s ~ a r e ~ a t ~ t h e ~ b a s i s ~}$ of a moral consensus; as such, they are profoundly political. As with the abovementioned paradox of revolution, while the law obviously cannot provide a place for the violation of the law, the contemporary fact that the actions of the disobedients were changing majority opinion "to an astounding degree" suggested to Arendt that their actions fit the "spirit" of American law. But the spirit must become letter. The Supreme Court had refused to intervene in the conduct of the war on the ground that a "political question" belonged to the other branches of government. This seemed to leave only one option: a constitutional amendment transcending the merely liberal guarantees of the First Amendment to actualize the politics whose spirit she had described ${ }^{28}$.

24 On Revolution, p. 9.

25 Civil Disobedience, p. 89.

26 Cf. for example, her reflections on the Pentagon Papers, 'Lying in Politics', which is reprinted as the first essay in the volume Crises of the Republic which contains also her 'Civil Disobedience'.

27 Ibid., p. 96.

28 "The establishment of civil disobedience among our political institutions might be the best possible remedy for this ultimate failure of judicial review" (ibid., p. 101). The argument developed here is foreshadowed at pages 83f. It may be worth noting that a District Court has invoked a similar "political question' doctrine in refusing the habeas corpus claim of a co-defendant of Saddam Hussein, denying that his being held in US military custody gave him standing for an appeal. Cf. New York Times, December $28,2006$. 
The reader of On Revolution will recognize in Arendt's constitutional proposal themes that Jefferson to his idea of a participatory "ward system" that could preserve the spirit of "public happiness" experienced in the American revolution. Although she insists that civil disobedience is "for the most part" an American tradition, Arendt seems to confirm Jonathan Schell's intuition when she adds that its necessity stems from a danger imposed by a government that, because it refuses to admit its own limits, "has changed voluntary association into civil disobedience and transformed dissent into resistance... [This threat] prevails at present - and, indeed, has prevailed for some time - in large parts of the world..." ${ }^{29}$ Although the "large parts of the world" do not share in the American "spirit" on which her claim is based, her argument here is broader, at once ontological, historical and based on political theory. Thus, the philosopher of The Human Condition stresses the ontological human ability to make promises; the political thinker of On Revolution recalls the historical experience dating from the Mayflower Compact and practiced in the New England townships; while the political theorist underlines the Lockean idea that society is bound together by compacts before it then creates a government ${ }^{30}$. The Lockean vision is the primary justification of civil disobedience because it implies that it is the government that violates the compact; and therefore it is the covenanted society (not an individual disobedient but rather the political power of individuals acting together) that must reassert itself in the face of this abuse. But this argument is only normative; it sacrifices the dynamic element of democracy - which was not, after all, Locke's still liberal concern.

Whatever we may think of Arendt's solutions, it is clear that her problems are also ours. Her list of misdeeds by the Vietnam-era government ring familiar: an illegal and immoral war accompanied by executive overreach, chronic deception of the public, restrictions on first amendment freedoms, and a government that forgets that the translation of the slogan e pluribus unam is not union sacrée ${ }^{31}$. Why, then, do we not see something like the kind of disobedient action against the Iraq excesses that she supported? Perhaps, as she suggests at one point, the plurality of divergent minds has become an ideological commitment that denies freedom of opinion, replacing political debate by ideological certainty - in the present case, the idea of "democracy" as solving "the age's problems" ${ }^{2}$ ? But elsewhere, after admitting, a bit reluctantly, that not everyone needs to participate in, or even be concerned with public affairs, she hopes that a self-selection process that draws out a "true political elite in a country" may produce "a new concept of the state. A council-state..." 33

29 Ibid., p. 102.

30 I noted earlier that Arendt did not know the 'republican' reading of the American revolution suggested most powerfully by Gordon Wood's Creation of the American Republic (in which it appears, for example, that Machiavelli was more important than Locke in the developing American revolutionary thought). I find her reading of Locke problematic, but she reaffirms her claims from On Revolution (pp. 160ff of the 2006 edition) in 'Civil Disobedience' (pp. 85ff).

31 Civil Disobedience, p. 94.

32 Ibid., p. 98. Arendt's worry was ideologies such as Maoism, Castroism, Stalinism... but today, on what passes for a Left, the more general form in which protest has tended to ossify is simple anti-Americanism.

33 In Thoughts on Politics and Revolution, p. 233. 
And her optimism only seems to fade in her last public presentation, "Home to Roost", (1975) when she describes a series of disasters in foreign and domestic politics culminating in a "swift decline in political power [that] is almost unprecedented." The institutions of liberty that have sustained the American spirit may be exhausted after surviving "longer than any comparable glories in history". Refusing to appeal to the truths of philosophy ${ }^{34}$, she won't abandon the spirit of freedom. "[W]hile we now slowly emerge from under the rubble of the events of the past few years", she concludes, "let us not forget these years of aberration lest we become wholly unworthy of the glorious beginnings two hundred years ago. When the facts come home to roost, let us try at least to make them welcome. Let us try not to escape into some utopias - images, theories, or sheer follies. It was the greatness of this Republic to give due account for the sake of freedom to the best in men and to the worst" ${ }^{35}$. I have italicized this last phrase for reasons that will become clear in my conclusions.

In the end, although she tried to avoid the traps of ontology and its historicist correlate $^{36}$ - stressing the diversity of "the human condition" - there is something troubling about Arendt's constant return to the "spirit" of the American founding. The "facts" on which she laid such great importance play a subsidiary role in On Revolution. As a result, it is difficult to know why the Americans have, or have not, met Franklin's challenge - "a republic if you can keep it"? Have they, as she at times suggests, fallen victim to the "antipolitics" of the party politicians? Have they, as she often fears, adopted the French revolutionaries' concern with the social question? Or is there, as I want to suggest, something about the very nature of democracy that constantly threatens it from within even as - for the same reason - it reinforces the power of a democratic polity and of its individual citizens? A closer look at the dynamic history from which Arendt distills the revolutionary "spirit" can help to explain also why Arendt's problems cast light on our own, and why ours in turn bring out the power of her vision. The "age's problems" are not defined by a specific historical conjuncture; they belong to an epoch whose decisive mark is that the challenge to maintain a republican democracy is accompanied by the threat of its antipolitical reversal. To recognize the two faces of this challenge is a step toward reclaiming the "ideals" that Jonathan Schell worries have been lost.

\section{Rethinking the American Revolution Today}

Despite her rejection of philosophy ${ }^{37}$, Arendt's stress on the uniquely human ability to covenant, to make promises, and to exchange opinions among a plurality of participants in public life, seems to be based on deep-rooted premises that are

34 'If it is in the nature of appearances to hide 'deeper' causes, it is in the nature of speculation about such hidden causes to hide and to make us forget the stark, naked brutality of facts, of things as they are'. 'Home to Roost', in Responsibility and Judgment, p. 260 (also for previous citation).

35 Ibid., p. 275. The italics are mine, D.H.

36 Every time that we have needed a new theory of politics we get instead a theory of history, she writes somewhere - in On History.

37 For a polemical interpretation, cf. Miguel Abensour, Hannah Arendt contre la philosophie politique (Paris: Sens \& Tonka, 2006). 
constantly present in what she called "the human condition." Granted, she is not describing the world from the perspective of a monadic subject; plurality, publicity and the fundamental concept of action guarantee a dynamic that makes humans capable of coming together to create a type of power that is distinct from the brute force of dumb nature. But how does this potential to produce the singular events that are the matter for political thought acquire its historical uniqueness? In the American case, an originary moment, ${ }^{38}$ the Mayflower Compact, is said to define the "condition" from which emerged the "spirit" that, in its turn, reappeared in the New England townships, in the Revolution, in the $19^{\text {th }}$ century form of associative life described by Tocqueville, and then in the $20^{\text {th }}$ century political action of the civil disobedients - before acquiring, in Jonathan Schell's argument, a new life in the "wave of democratic revolutions". Plus ça change, plus c'est la même chose. But: tant mieux! I like this vision. But I'm not sure how it helps to understand either the American revolution or the way that historical experience illuminates contemporary political problems.

It is of course unfair to reduce Arendt's analysis to a concern with something so vague as a revolutionary spirit. An important thread in her analysis is suggested by her claim that "the great and, in the long run, perhaps the greatest American innovation in politics as such was the consistent abolition of sovereignty within the body politic of the republic, the insight that in the realm of human affairs sovereignty and tyranny are the same." 39 This question of sovereignty, which was crucial to the movement that led to each new phase of the revolution, suggests the need to think today about the implications of an event that marked the culmination of the revolutionary wave: "the revolution of 1800", which brought the republicans of Thomas Jefferson to power ${ }^{40}$. Reflection on that event, in turn, helps to make clear what Arendt might have meant by "the age's problems". That, in turn, suggests why her problems illuminate ours just as ours cast light on her own mode of thinking about politics.

\section{The 'revolution of 1800 '}

The American revolution passed through three phases before its initial impetus was realized (and the classical theory of sovereignty rejected in favor of a republicandemocratic practice). The first period, from 1763 to 1776, posed the question of sovereignty. After the British victory in the Seven Years' War - called naively by the

38 I use the concept of 'origin' in a specific sense that I illustrate in Aux origines de la pensée politique américaine, op. cit. Its systematic foundation is developed in From Marx to Kant.

39 On Revolution., p. 144. The same phrase was cited by Andrew Arato in 'Banishing the Sovereign? Arendt's America and Ours,' presented at Yale University, September 2006.

40 This was the name given it by its contemporaries, although historians have neglected its implication. To my knowledge there exists a single book on the topic, The American Revolution of 1800 by Daniel Sisson (New York: Knopf, 1974). There is no mention in this context of the ward system, of which Jefferson spoke only years later, and in private correspondance. 
Americans the "French and Indian War" - the colonists no longer needed the protection of the mother country; but Britain now needed to reorganize relations among the parts of its enlarged empire and to pay the debts it had incurred in the process. This led to a series of measures that, to the colonists, seemed an impingement on their rights and liberties. Often summed up in the lapidary phrase, "No taxation without representation", the stream of pamphlets produced during these years began with attempts at conciliation only to be drawn, inexorably it seems, to articulate what Tom Paine expressed as simply "Common Sense" ${ }^{41}$. In retrospect, one theoretical argument coupled with practical experience made the rupture seem necessary. On the plane of theory, John Dickinson showed that local self-government implied an imperium in imperio, which was a contradiction in political terms. This logical argument carried weight because practical experiences of self-management, such as the refusal of the Stamp Act or the non-importation actions on the part of the colonies proved that political legitimation from Britain was not needed for the Americans to run their own lives. Thus was born in practice and theory the revolutionary spirit.

The new self-understanding won in the first period had to be defended once independence was proclaimed. The war began poorly; in the bitter winter of 1776, at Valley Forge, General Washington ordered that Tom Paine's new pamphlet, The American Crisis, be read to the troops. "These are the times that try men's souls", wrote Paine, as he denounced "[t]he summer soldier and the sunshine patriot..." Political events don't just happen; individuals participate when they exercise their judgment ${ }^{42}$. Finally, the army held; French help began to arrive. Meanwhile, it remained for the Americans to give themselves new institutions of government. As in the first political phase of the revolution, theoretical reflection joined with practical experience. The theory was condensed in the efforts of John Adams, whom Arendt invokes frequently. But while she rightly stresses his debt to the constitutional schemes of Montesquieu, it is his insistence that government must be a "representation in miniature" of the people whom they represent that became crucial to the development of American political self-understanding. The implication of Adams' proposition was drawn more sharply by the practical experience of the new state of Pennsylvania. For reasons that were circumstantial ${ }^{43}$, its radical democratic constitution provided for frequent elections, a weak executive, periodic review of all

41 Paine's best-selling pamphlet appeared in early 1776; for his part, Jefferson denied any originality in his Declaration, which he saw as expressing a shared sense of the colonists.

42 Chief Justice John Roberts has suggested recently that the antagonism between President Jefferson and Chief Justice John Marshall stems from the latter's 'ill-feeling...that Jefferson was not at Valley Forge, was not in the fight, and had what Marshall might regard as a somewhat precious attachment to ideas for the sake of ideas...' Cited in Jeffrey Rosen, 'Roberts's Rules', The Atlantic, January/February 2007, p. 106.

43 Pennsylvania was a proprietary colony ruled by the Penn family. Those leaders who, in the other colonies, had directed the struggle with Britain had been attempting to give it greater independence by making it a crown colony. As a result, when independence came, they were discredited. An artisan class replaced them in the crucial period of constitution-making. 
laws by a council of censors among other popular measures. While approximating a direct democracy, this constitution was also a recipe for instability. And although the Pennsylvania model was more radical, both of these constitutions suggested that the Americans' conception of the sovereignty for which they were fighting was that of a democracy in which the people were full participants. But, when peace was finally made (in 1783), the sovereignty that had been won could not be maintained in the face of post-war economic problems made worse by inter-state rivalries that blocked the functioning of the loosely knitted confederal government. The conception of sovereignty for which they fought needed modification ${ }^{44}$.

A new stage in American political thought and practice was reached not only with the constitutional creation of 1787, but also in the process of its popular ratification. As Arendt recognized, the letter of the institution has to be structured in such a way that the spirit that presided at its origin can be maintained (or renewed). The new understanding that emerged in this third phase is presented in the Federalist Papers, which are at once a political act (within the ratification process) and a theoretical self-reflection. Two arguments are crucial; and their relation must be properly understood. The first is Federalist 10 , which defends the possibility of a large republic by recourse to the idea that its safety and vitality will be guaranteed by the presence of competing factions. The second is elaborated in Federalist 51, which insists that the safety and vitality of the republic will be guaranteed by the checks-and-balances among the branches of the new government. It would seem that if one of these claims is true, the other is not necessary - or indeed, that if both are valid, the resulting constitution may limit itself too greatly, making swift and decisive action impossible. However, when put in the context of the debate over sovereignty, the two claims are saying one and the same thing: Federalist 10 explains that "the" sovereign people as such does not exist, while Federalist 51 draws the conclusion that any branch of government that claims to incarnate the vox populi is exceeding the power accorded it by the constitution ${ }^{45}$. However, because the constitution both checks and balances the power of a democratic people, there will be present always that dynamic that, beginning already in the first phase of the revolution, seeks to realize its own democratic self-government. The

44 The passage from the Articles of Confederation to the Constitution of 1787 - as well as the different institutional forms adopted in Massachusetts and Pennsylvania - should not be interpreted in terms of economic interests. Arendt offers a stinging rebuke to those who follow Charles Beard's Economic Interpretation of the Constitution of the United States (1913). Their insistence on tactics of 'unmasking' and denunciations of 'hypocrisy' belongs to French-style historiography. Cf. On Revolution, p. 89.

45 A third argument, that of Federalist 63, could be added to reaffirm the point being made here while raising also the question of representative democracy. That argument concerns the legitimacy of a Senate in a society which has no constituted aristocracy. The justification offered in Federalist 63, which freely admits that American democracy is not direct but representative, depends also on the symbolic nature of the sovereignty that is to be represented by that upper branch of the legislature. For details, cf., Les origines de la pensée politique américaine, op. cit. 
inherent paradox of the American republic is that it solicits popular sovereignty even while making its complete realization impossible ${ }^{46}$.

This historical dynamic reached a temporary resolution with the "revolution of 1800 ", which marked the first peaceful passage of political power from one party to another. After a bitter campaign foreshadowed by the repressive Alien and Sedition laws (1798) and heated by reciprocal accusations of "monarchism" and "jacobinism", Jefferson assumed the presidency and Adams returned quietly home to Massachusetts. Jefferson's inaugural Address alluded to the campaign, but insisted that "every difference of opinion is not a difference of principle. We have called by different names brethren of the same principle. We are all Republicans, we are all Federalists" ${ }^{47}$. It is significant that Jefferson did not mean that party differences would - or could, or should - be abolished ${ }^{48}$. The unity that binds together the republic is what he calls here a unity of principle. The nature of that principle was demonstrated in the second moment of the revolution of 1800, the Supreme Court's decision in Marbury v. Madison (1803). The court's ruling can be interpreted as arguing that while Jefferson's republicans were now the majority, their power remained limited; it is the principles of the constitution that constitute the always present but never fully realized, or realizable, sovereignty of the people. It is the constitution that guarantees that the people are One at the same time that its institutional structure assures that the momentary expression of that unity is realized only through the constant production of difference, debate and deliberation. The "revolution of 1800" is thus an event that is more than an event; it confirms the experience of and reflection on the American revolution and can be taken as the expression of that "spirit" invoked by Arendt.

This interpretation of the foundation of American democracy in terms of the problem of sovereignty can be developed further. As a "principle", sovereignty is symbolic; because it depends on judgement rather than will, its momentary expression is always open to negotiation; it can never be incarnated once-and-forall yet it is the constant presence without which neither a polity nor the individuals that compose it can subsist. More concretely, the history of American democracy can be thought of as the constant competition among institutions that claim to represent the will of the sovereign. The actors in the resulting dynamic process are not only the legislative, executive and judicial branches (and the federal states);

46 That is why, in The Specter of Democracy, I distinguish between the American form of a republican democracy and the French variant that seeks to create a democratic republic in which the society is fully incarnate in a republican political state. Although Hannah Arendt doesn't use this language, it certainly is not foreign to the theses of On Revolution.

47 Thomas Jefferson, 'First Inaugural Address', in Writings (New York: The Library of America, 1984), p. 493.

48 In fact, with the presidency of the third of the great republican presidents, James Monroe (1816-1824), America entered what was called The Era of Good Feeling, during which party competition had disappeared at the national level. The result was the so-called 'Corrupt Bargain: by which John Quincy Adams became president. The reaction was not long in coming: the populism that brought Andrew Jackson to power in 1828. 
new players emerge, be they political parties, groups claiming power through expertise, specialized interests or the inexorable forces of global markets...or the non-violent power of civil disobedients. While one or another institution may come to dominate for a time, it is important to recognize that as long as the principle remains, as long as sovereignty remains symbolic, there will surely emerge others who will contest the legitimacy and dispute the monopoly that is asserted. Rather than a direct democracy in which the sovereign and unitary will of society is expressed in its political institutions - what I have called elsewhere a "democratic republic" - the Americans created what can be called a "republican democracy" whose institutional structure encourages individuals to actively judge among choices available and to participate together in the self-determination that is needed to "keep" the republic they have inherited.

\section{Conclusion}

These reflections on the historical events of the American revolution bring us back to what Arendt called "the age's problems." Every political actor of course claims that its policies are the incarnation of the united will of the nation and that its platform opens the path to Smiling Tomorrows. But the door to antipolitics is opened if the symbolic - and therefore contested - nature of the sovereign people is reduced to its temporary reality. That is the crucial lesson to be drawn still today from The Origins of Totalitarianism, which can be read as an attempt to think the most extreme expression of antipolitics. The extreme casts light on the everyday; and it underlines the actuality of Benjamin Franklin's elliptic phrase, "A republic, if you can keep it." That is why the politics of human rights - as a politics, not as simply the protection of private freedoms (as Arendt rightly noted in the discussion of "Civil Disobedience") - is fundamental to a republican democracy. It is an error to think that the "democracy" that triumphed in 1989 was the solution to the "age's problems". Re-reading of On Revolution suggests, rather, that those events make clear - yet again - that democracy is a dangerous game that can easily lose its way when democrats forget how to think, which means to recognize the limits of a political process that is by its very nature unlimited. Just before she insisted that the "greatest American innovation" was the abolition of sovereignty, Arendt cited Montesquieu's "famous insight that even virtue stands in need of limitation and that even an excess of reason is undesirable..." 49 If too little democracy is certainly a default, the attempt to realize it once-and-for all (by force, if needed) can prove to be a more grievous threat. Those "ideals" that Jonathan Schell wanted us to reclaim have to be understood in this context.

49 On Revolution, p. 143. 